\title{
Implemantasi Fatwa MUI tentang Akad Mudharabah terhadap Produk Tabungan Safari Kospin Jasa Syariah Banjaran Tegal
}

\author{
Nurul Wulandari Putri ${ }^{1}$, Dhiya Faras Febriani ${ }^{2}$ \\ ${ }^{1}$ Sekolah Tinggi Ilmu Ekonomi Syariah Putera Bangsa, Tegal \\ Email: nwulandariputri@gmail.com \\ ${ }^{2}$ Universitas Islam Indonesia \\ Email: dhiyafaras52@gmail.com
}

\begin{tabular}{|c|c|}
\hline Keywords: & Abstract: \\
\hline $\begin{array}{l}\text { Keywords: Islamic } \\
\text { economy, Savings } \\
\text { Safari, Fatwa DSN } \\
\text { MUI }\end{array}$ & $\begin{array}{l}\text { Indonesia as a majority Muslim community, has a strong spirit to develop a sharia } \\
\text { economic system in everyday life. In the face of today's uncertain global economy, it is } \\
\text { necessary for every individual to have a savings fund in life. Kospin Jasa Syariah Capem } \\
\text { Banjaran is here to present various products that are needed by the wider community, } \\
\text { one of which is the Safari Savings product. The purpose of this study is to determine the } \\
\text { implementation of the application of the Fatwa DSN MUI on the Safari Savings product } \\
\text { at Kospin Jasa Syariah Capem Banjaran. With descriptive qualitative method, the writer } \\
\text { wants to know in detail the application of the fatwa in the field. The results of this study } \\
\text { indicate that Kospin Jasa Syariah uses the mudharabah muthlaqah contract on the } \\
\text { Safari Savings product, which is done in writing and the ratio is expressed as a } \\
\text { percentage. However, in practice the safari savings product contains several points that } \\
\text { are not in accordance with the fatwa DSN MUI, namely profits are not calculated clearly } \\
\text { and Kospin Jasa Syariah sets the same nominal ratio until the end of the contract to } \\
\text { customers. }\end{array}$ \\
\hline Kata kunci: & Abstrak: \\
\hline $\begin{array}{l}\text { Kata Kunci: } \\
\text { Ekonomi Islam, } \\
\text { Tabungan Safari, } \\
\text { Fatwa DSN MUI }\end{array}$ & $\begin{array}{l}\text { Indonesia sebagai masyarakat mayoritas beragama Islam, memiliki semangat yang kuat } \\
\text { untuk mengembangkan sistem ekonomi syariah dalam kehidupan sehari-hari. Dalam } \\
\text { menghadapi perekonomian global yang tidak menentu saat ini, perlu sekiranya setiap } \\
\text { individu memiliki dana tabungan dalam kehidupan. Kospin Jasa Syariah Capem } \\
\text { Banjaran hadir dalam hal ini hadir mempersembahkan berbagai produk yang dibutuhkan } \\
\text { masyarakat secara luas salah satunya melalui produk Tabungan Safari. Tujuan dari } \\
\text { penelitian ini yaitu untuk mengetahui implementasi penerapan Fatwa DSN MUI pada } \\
\text { produk Tabungan Safari pada Kospin Jasa Syariah Capem Banjaran. Dengan metode } \\
\text { kualitatif deskriptif penulis ingin mengetahui secara detail penerapan fatwa tersebut di } \\
\text { lapangan. Hasil penelitian ini menunjukkan bahwa Kospin Jasa Syariah menggunakan } \\
\text { akad mudharabah muthlaqah pada produk Tabungan Safari, yang dilakukan secara } \\
\text { tertulis dan nisbah yang dinyatakan dalam persentase. Akan tetapi, dalam praktinya } \\
\text { produk tabungan safari terdapat beberapa poin yang tidak sesuai dengan fatwa DSN MUI } \\
\text { yaitu keuntungan tidak dihitung dengan jelas dan Kospin Jasa Syariah menetapkan } \\
\text { nominal nisbah yang sama sampai berakhinya akad kepada para nasabah. }\end{array}$ \\
\hline
\end{tabular}

\section{Pendahuluan}

Received: February 14, 2021. Revised: July 12, 2021. Accepted: July 13, 2021

Perkembangan ekonomi syariah di Indonesia satu sisi melahirkan kegembiraan dan optimisme masyarakat muslim Indonesia akan masa depan ekonomi islam sebagai sebagai sistem ekonomi alternatif. Namun disisi lain harus mengehadirkan tanangan baru untuk peningkatan kualitas yang lebih baik. Kita lihat sekarang mulai marak industri keuangan non-bank yang memberikan dampak yang baik untuk perekonomian indonesia khususnya dikalangan menengah kebawah, dengan perkembangan ini 
banyak masyarakat menuntut akan jasa perbankan yang bebas akan praktik riba. Didukung dengan konsep muamalah dengan berbagai akad yang ada sudah mulai dikembangkan secara praktis sesuai dengan persoalan aktal dan kotemporer, diantaranya akad mudharabah, musyarakah, dll serta hal yang berkaitan dengan zakat dan wakaf. Secara riel telah dikeluarkan bebagai macam fatwa yang disahkan oleh DSN (Dewan Syariah Nasional) Majelis Ulama Indonesia sebagai pedoman praktis bagi masyarakat publik dalam bermuamalah sesuai dengan syariah. Kemudia fatwa-fatwa tersebut harus dikawal dalam tataran aplikatif pada masyarakat.

Hal ini perlu disyukuri dan diapresiasi, perkembangan ini tidak hanya dijumpai dalam tataran wacana yang bersifat teoritik-Normatif, akan tetapi sudah sampai dalam tatanan lebih praktis-aplikatif. Diantaranya bermunculan Lembaga keuangan Syariah yang bermunculan di masyarakat. Lembaga keuangan mikro ini merupakan pendekatan dari pembangunan ekonomi sebagai pemberi manfaat bagi orang-orang yang berpenghasilan menengah kebawah. Dalam hal ini lembaga keuangan mikro adalah lembaga keuangan yang didirikan khusus untuk memberikan jasa pengembangan usaha serta pemberdayaan masyarakat. Lembaga Keuangan Mikro Syariah di Indonesia memberikan gambaran bahwa sistem ekonomi Islam dapat beradaptasi dengan baik dengan perekonomian konvensional. Sehingga perkembangan dari ekonomi Islam sendiri di Indonesia terbilang cepat terutama untuk perbankan, asuransi dan pasar modal (Saepudin, 1987).

Permasalahan kesenjangan sosial menjadikan topik utama dalam dunia perekonomian, namun bukan hanya perekonomian untuk wilayah Indonesia saja tetapi juga berlaku untuk negara lain. Dalam upaya meminimalkan resiko kemiskinan, maka diperlukan Lembaga Keuangan Mikro yang berbasis Syariah yang memperhatikan masyarakat, teruntama untuk masyarakat kalangan menengah ke bawah. Sehingga adanya Lembaga Keuangan Mikro Syariah dapat menjadi solusi bagi orang yang membutuhkan dana maupun kelebihan dana. Dalam Lembaga Keuangan Mikro Syariah terdapat beberapa bentuk lembaga yang melliputi Koperasi Syariah, BMT, dan BPRS.

Koperasi merupakan badan usaha yang didirikan oleh perorangan atau suatu badan hukum yang mempunyai fungsi yaitu untuk memenuhi kebutuhan anggotanya dan bertujuan untuk memajukan perekonomian para anggotanya (Suhendi, 2007). Koperasi sendiri beroperasi dalam pelayanan jasa koperasi simpanan dan pinjaman. Dalam hal ini Kospin Jasa Syariah harus mampu bersaing dengan Lembaga Keuangan Mikro Syariah lainnya dan juga bersaing dengan Lembaga Keuangan Mikro Konvensional. Kospin Jasa Syariah memberikan suatu hal yang berbeda dengan Lembaga Keuangan Mikro Syariah lainnya, dengan memberikan berbagai produk yang dapat membantu kebutuhan masyarakat sekitar

Diantara produk yang dimiliki koperasi ini berupa Tabungan Safari (Sadar Manfaat Berkoperasi), yaitu tabungan dengan sistem berjangka yang menerapkan sistem bagi hasil dengan bentuk pariwisata serta Tabungan Safari dalam hal ini memberikan keuntungan setiap bulannya kepada nasabah dalam bentuk hadiah sejumlah uang dan motor dengan akad awal menggunakan Mudharabah. Akad Mudharabah yaitu akad dengan nasabah maupu deposan bertindak sebagai shohibul mal dan lembaga keuangan sebagai mudharib. Bilamana di kemudian hari mengalami kerugian maka lembaga keuangan akan bertanggungjawab atas kerugian yang terjadi (Muhammad, 2014).

Setiap produk yang ada di perbankan maupun lembaga keuangan syariah wajib memiliki pengawas, untuk bidang syariah maka pengawasan ini akan dilakukan oleh Dewan Pengawas Syariah (DPS) yang mana guna mengotrol apakah produk yang ada telah memenuhi prinsip-prinsip dalam Islam. Sama halnya dengan produk tabungan safari itu sendiri maupun mengawasi lembaga keuangan syariah secara menyeluruh, Dewan Pengawas Syariah (DPS) dalam hal ini akan mengatur bagaimana pelaksanaan akad mudharabah dalam produk tabungan safari apakah telah sesuai dengan Fatwa MUI No. 115/DSN-MUI/IX/2017 tentang ketentuan hukum bentuk mudharabah, shighat akad, nisbah (bagi hasil), pembagian keuntungan dan kerugian, ketentuan aktivitas serta produk LKS dan lain sebagainya. 
Peneliatian ini dilakukan sebagai upaya cek and balance kondisi yang ada dilapangan dengan peraturan dan ketentuan yang telah disepakati. Karena kepatuhan syariah merupakan pilar penting dalam pengembangan lembaga keuangan syariah. Kepatuhan syariah ini menjadikan lembaga keuangan syariah berbeda dengan lembaga keuangan konvensional, kepatuhan syariah yang merupakan sebagai pemenuhan dari seluruh prinsip syariah yang harus ditaati dalam lembaga keuangan syariah atau perbankan syariah dengan menggunakan Fatwa DSN MUI.

\section{Metodologi}

Penelitian ini menggunakan metode penelitian kualitatif dengan pendekatan analisis isi (content analysis). Penelitian kualitatif merupakan metode penelitian naturalistik karena penelitiannya yang dilakukan pada kondisi dimana kondisi yang alamiah atau natural setting yang mana metode ini digunakan untuk meneliti pada kondisi obyek alamiah yang mana penulis sebagai instrumen kunci, teknik pengumpulan data bersifat induktif, dan hasil yang didapatkan dalam metode penelitian kualitatif ini lebih menekankan pada makna dari pada generalisasi (Sugiyono, 2013). Menurut Weber mengatakan bahwa Analisis isi (content analysis) merupakan metodologi yang dapat memanfaatkan seperangkat prosedur untuk menarik suatu kesimpulan yang benar dari suatu buku atau dokumen tertentu (Komariah, 2009).

Objek yang digunakan dalam penelitian ini adalah Kospin Jasa Syariah Capem Banjaran dan nasabah Kospin Jasa Syariah Capem Banjaran yang menggunakan produk tabungan safari dengan alamat lokasi penelitian di Jalan Raya Utara Adiwerna No. 06, Banjaran, Kalimati, Kecamatan Adiwerna, Kabupaten Tegal, Jawa Tengah. Data primer dalam bentuk wawancara langsungdengan pihak Kospin Jasa Syariah maupun dengan nasabah yang menggunakan produk tabungan safari serta data sekunder dalam bentuk referensi-referensi pendukung seperti halnya brosur dan laporan perusahaan, yang mana keduanya adalah sebagai sumber data dalam penelitian ini.

\section{Hasil dan Pembahasan}

\section{a. Kepatuhan Praktik Syariah}

Sebuah lembaga pasti memiliki aturan dan ketentuan masing-masing dan telah disepakati bersama, sehingga memiliki tanggungjawab kepatuhan atas aturan yang ada. Konsep kepatuhan syariah merupakan standar atau hukum yang telah diatur suatu organisasi atau lembaga yang memiliki wewenang dalam bidang tersebut. Dan syariah menurut bahasa arab yaitu jalan yang harus diikuti. Sehingga kepatuhan syariah menurut Arifin, penerapan prinsip-prinsip syariah baik dalam transaksi keuangan maupun perbankan ataupun bisnis lainnya (Arifin, 2009). Kepatuhan syariah adalah pemenuhan prinsip syariah dalam suatu lembaga yang memiliki karakteristik, intergritas dan kredibilitas di bank syariah, arti dari kepatuhan syariah secara operasional sendiri merupakan kepatuhan pada Fatwa Dewan Shariah Nasional (DSN) karena fatwa DSN MUI sendiri merupakan poros dari prinsip dan aturan syariah yang harus ditaati oleh lembaga keuangan syariah baik perbankan syariah ataupun lembaga lainnya (Sutedi, 2009).

Kepatuhan syariah ini mencakup semua aspek yang ada di perbankan syariah, baik produk maupun transaksinya. Dalam kepatuhan syariah tidak hanya meliputi operasionalnya saja tetapi juga dalam sistem, teknik maupun identitas dari perusahaan tersebut (Indonesia, Peraturan Bank Indonesia Tentang Pelaksanaan Fungsi Kepatuhan Bank Umum, 2011). Pemegang kebijakan perbankan di Indonesia sendiri yaitu Bank Indonesia telah menjadikan Fatwa DSN MUI sebagai poros bagi perbankan syariah. Yang artinya Bank Indonesia menjadikan Fatwa DSN MUI sebagai peraturan bagi Bank Indonesia dalam aspek kepatuhan syariah. Dalam hal ini Fatwa DSN MUI digunakan untuk menciptakan keseragaman norma-norma aspek syariah dalam produk-produk perbankan syariah. 
Ketentuan ini digunakan untuk menilai tingkat kepatuhan syariah yang ada didalam lembaga keuangan syariah. Ketentuan ini meliputi: 1) Akad atau kontrak yang akan digunakan untuk pengumpulan dan penyaluran dana sesuai dengan prinsip-prinsip syariah dan aturan syariah yang telah berlaku 2) Dana zakat dihitung, dibayar serta dikelola sesuai dengan aturan prinsip-prinsip syariah yang telah berlaku 3) Seluruh transaksi dan aktivitas ekonomi yang dilakukan oleh Lembaga Keuangan Syariah akan dilaporkan sesuai dengan standar akuntasi syariah yang berlaku 4) Lingkungan kerja ataupun corporate culture yang sesuai dengan prinsip-prinsip syariah 5) Bisnis usaha yang akan dibiayai tidak melanggar prinsip-prinsip syariah 6) Terdapat Dewan Pengawas Syariah (DPS) sebagai penunjuk atas keseluruhan aktivitas operasional yang ada di lembaga keuangan syariah. 7) Sumber dana yang didapatkan berasal dari sumber daya yang sah dan halal menurut syariah. Ketentuan-ketentuan diatas merupakan prinsip umum yang akan menjadi acuan bagi manajemen lembaga keuangan syariah dalam mengoperasikan suatu kegiatan yang ada di lembaga keuangan syariah. Kepatuhan syariah dalam lembaga keuangan syariah sendiri dinilai dari ketentuan-ketentuan tersebut untuk mengetahui apakah operasional dari lembaga keuangan syariah telah sesuai dengan ketentuan umum yang ada dalam kepatuhan syariah (Sutedi, 2009).

Indikator dari kepatuhan syariah merupakan tolak ukur dari suatu nilai yang digunakan untuk menilai dari suatu penelitian. Fatwa Dewan Syariah Nasional Majelis Ulama Indonesia digunakana sebagai salah satu indikator dari kepatuhan syariah yang dilakukan oleh lembaga keuangan syariah ataupun unit usaha syariah. Dimana Fatwa DSN MUI No: 115/DSN-MUI/IX/2017 tentang akad mudharabah sebagai pilar dalam kepatuhan tersebut. Diantara isinya tentang ketentuan umum mengenai akad mudharabah adalah akad kerja sama dalam usaha antara pemilik modal yang menyediakan seluruh dana (shahibul al-mal) dengan pengelola (mudharib) dan dari usaha ini akan mendapatkan keuantungan yang akan dibagi sesuai dengan nisbah yang telah disepakati saat akad. Shahibul amal adalah penyedia dana dalam kerja sama usaha mudharabah. Baik berupa orang (syakhshiyah thabi'iyah) maupun yang dipersamakan dengan orang, baik berbadan hukum maupun tidak berbadan hukum (syakhshiyah i'tibariah). Amil/mudharib adalah pengelola dari dana tersebut dalam kerja sama usaha mudharabah. Baik berupa orang (syakhshiyah thabi'iyah) maupun yang disamakan dengan orang, baik berbadan hukum maupun tidak (syakhshiyah i’tibariah). (DSN MUI, 2017)

\section{b. Tabungan Safari Kospin Jasa Syariah Banjaran}

Tabungan Safari ini merupakan salah satu produk simpanan yang dimiliki oleh Kospin Jasa Syariah, sistem produk tabungan safari adalah dengan metode arisan. Sistem arisan tersebut akan dilakukan dengan cara penyaringan setiap bulan, serta akad yang digunakan dalam tabungan safari adalah menggunakan akad mudharabah. Kelebihan Tabungan Safari ini dibandingkan produk yang lain adalah dengan mengajak nasabah produk tabungan safari untuk gathering serta berlibur bersama-sama dengan nasabah produk tabungan safari yang lain ke tempat wisata secara Cuma-Cuma, dengan periode jangka waktu tabungan ini adalah 2 tahun 6 bulan, dengan angsuran perbulan sebesar Rp.350.000. Tetapi saat pandemi corona seperti ini, pihak Kospin Jasa Syariah meniadakan wisata yang biasa dilaksanakan pada bulan September atau Oktober, terakhir pelaksanaan wisata sendiri September tahun 2019 yaitu ke wisata Saloka Semarang. Untuk Sistem pembayaran setoran Tabungan Safari sendiri yaitu menggunakan sistem debet rekening yang dilakukan dengan cara pemotongan dana tabungan pusat secara otomatis pada tanggal 15-25 setiap bulannya. (Kuniawan, 2020)

Fasislitas yang nantinya akan di dapatkan nasabah Tabungan Safari, adalah: Pertama, kemanan terjamin, karena Kospin Jasa Syariah sudah terdaftar dalam OJK (otoritas jasa keuangan syariah) maka sudah jelas segala transaksi yang ada aman serta terjamin kesyariahannya karena Kospin Jasa Syariah memiliki Dewan pengawas syariah (DPS) sebagai penjamin atas kesyariahan produk yang ada. Kedua, Memiliki rekening induk (Takop). Ketiga, Bebas dari biaya administrasi. Keempat, Peserta yang menyetor tabungan secara rutin berhak mengikuti wisata gratis. Kelima, Peserta yang tidak pernah 
memiliki tunggakan selama 2 tahun 6 bulan berhak mendapatkan souvernir dari Kospin Jasa Syariah berupa berupa uang sebagai hadiah utama yang akan diundi tiap bulan tetapi untuk nasabah yang selama program tabungan safari pernah menunggak atau tidak lancar selama setoran maka tidak berhak mendapatkan souvernir dari Kospin Jasa Syariah. Keenam, Peserta yang saat penyaringan ternyata mendapatkan hadiah utama maka kepesertaannya dalam Tabungan Safari gugur serta sisa setoran yang harus dibayarkan akan gugur, sebagai contoh apabila ibu A telah setor tabungan selama 9 bulan lalu ternyata dalam undian bulanan ibu A mendapatkan hadiah tersebut maka sisa bulan yang seharusnya diangsur menjadi gugur. Ketujuh, Peserta yang dalam pengundingan tidak mendapatkan hadiah utama serta tidak memiliki tunggakan maka akan mendapatkan pencairan seluruh tabungan, serta akan mendapatkan hadiah tambahan dalam bentuk sepeda motor yang akan diundi di akhir periode.

Secara prinisp akad Mudharabah adalah pihak bank berlaku sebagai mudharib yang mana akan mengelola dana dari pihak nasabah atau penyedia dana, dalam hal ini dana tersebut dapat dipergunakan sebagai dana usaha, yang nantinya setelah dana tersebut diolah harapannya akan mendapatkan hasil atau keuntungan, serta keuntungan tersebut nantinya akan dibagikan kepada bank dan nasabah sesuai saat awal perjanjian. selain itu untuk nisbah Kospin Jasa Syariah Capem Banjaran menggunakan aturan dari kantor pusat Kospin Jasa Syariah dan untuk mengetahui berapa jumlah nisbah yang ditentukan pihak Kospin Jasa Syariah tidak memberitahu karena sifatnya privasi. Terdapat tim peneliti dari kantor pusat untuk menentukan tujuan wisata yang akan dilaksanakan. Penentuan wisata ini mengikuti kondisi ekonomi yang terjadi, dengan melihat cost. Jika cost lebih murah, maka wisata yang dituju bisa saja mahal.

Produk tabungan safari tersebut dalam pengaplikasian menggunakan dari akad mudharabah sesuai pada kesepakatan diawal, yang mana dalam hal ini pihak nasabah berlaku sebagai penyedia dana atau shahibul mal sedangkan pihak Kospin Jasa Syariah berlaku sebagai pengelola dana. Dengan harapan dari pengolahan dana ini, pihak Kospin Jasa Syariah akan memberikan bagi hasil setelah dana tersebut diolah kepada nasabah produk tabungan safari berdasarkan dengan nisbah yang telah disepakati diawal akad. Dana peserta yang diinvestasikan memiliki perbandingan bagi hasil sejumlah 0,05\% dan pembayaran bagi hasil akan diberikan diakhir jangka waktu Tabungan Safari yang telah ditentukan. Dalam perjanjian tertera bahwa jika peserta menarik atau mengambil tabungan sebelum jatuh tempo maka akan dikenai denda atau penalty. Nisbah yang ditetapkan oleh Kospin Jasa Syariah pada produk Tabungan yaitu $0,05 \%$ untuk nasabah dan $99,5 \%$ untuk bank.

Dalam penetapan nisbah ini, nantinya akan menjadi acuan untuk menetapkan hasil dari bagi hasil. Seperti penjelasan dari Pak Lilik Kurniawan dalam wawancaranya, mengatakan: "Nisbah yang digunakan yaitu sebesar $0,05 \%$, nisbah ini sudah ditetapkan oleh pusat. Nisbah ini akan dikalikan dengan pendapatan yang diperoleh, jika cost murah maka bisa saja wisata yang akan didapatkan semakin mahal" (Kuniawan, 2020). Kospin Jasa Syariah menerapkan nisbah sebesar 0,05\% pada Tabungan Safari. Nisbah yang akan dikalikan dengan pendapatan, nantinya akan menentukaan wisata yang diperoleh besar kecilnya dari hasil bagi hasil tersebut.

Wawancara yang dilakukan bersama Ibu Desi Nitasari selaku karyawan Kospin Jasa Syariah capem banjaran mengatakan bahwa: "Produk Tabungan Safari adalah tabungan dengan sistem perjanjian antara dua pihak yakni pihak Kospin Jasa Syariah sebagai pengelola dan nasabah produk tabungan safari sebagai penabung. Dalam prosesnya, Kospin Jasa Syariah bebas untuk melakukan pengolahan dana tersebut serta harapannya di kemudian hari akan memberikan bagi hasilnya berupa keuntungan kepada nasabah produk tabungan safari. Dana atau modal yang diberikan oleh nasabah Kospin Jasa Syariah, dana tersebut tetap ada di outstanding saldo perusahaan. Tabungan Safari sendiri memiliki peluang cukup bagus untuk Kospin Jasa Syariah yaitu belum banyaknya lembaga keuangan syariah yang memiliki produk tabungan sekaligus mendapatkan jalan-jalan gratis dengan uang tabungan 
yang utuh tanpa dikenai biaya. Kondisi alam saat dilaksanakannya wisata tersebut menjadikan ancaman bagi Kopin Jasa Syariah sehingga lebih memantangkan untuk menentukan tujuan wisata.

Nasabah Tabungan Safari sendiri tiap tahunnya meningkat yaitu sekitar 990 nasabah. Ini menjadikan sebagai peluang yang besar bagi Kospin Jasa Syariah dengan pelayanan yang diberikan yang terbilang ramah dan baik. Beberapa fasilitas yang didapat mendapat dampak karena adanya pandemi corona. Seperti wisata yang biasanya dilaksanakan pada bulan september atau oktober harus diundur. Tetapi seperti undian hadiah, baik hadiah utama berupa uang tunai maupun hadiah ekstra tidak terkena dampaknya dan pengembalian dana Tabungan Safari pun tidak terkena dampaknya sehingga untuk pengembalian sesuai dengan berakhirnya periode masing-masing nasabah produk tabungan safari." (Nitasari, 2020).

Secara teoritis bahwa produk tabungan yang dibenarkan adalah tabungan yang prinsipnya menggunakan akad wadiah maupun akad mudharabah. Apabila pihak bank atau lembaga keuangan syariah menggunakan akad mudharabah muthlaqah maka artinya tentu saja bank akan bebas menggunakan dana atau mengelola dana yang diberikan oleh shahibul mal (nasabah atau pemilik dana), tanpa ada campur tangan dari pemilik dana atau shahibul mal.

\section{c. Implementasi Fatwa MUI Terhadap Produk Tabungan Safari}

Dari hasil penelitian yang telah peneliti lakukan pada Tabungan Safari di Kospin Jasa Syariah dengan Fatwa DSN MUI No. 115/DSN-MUI/IX/2017 tentang akad mudharabah sebagai berikut: Pertama, Kospin Jasa Syariah mewajibkan nasabah untuk membawa fotocopy KTP. Poin pertama Ini sudah sesuai dengan ketentuan yang berlaku yakni terkait ketentuan dari Fatwa DSN MUI No. 115 tahun 2017 pada butir ke 4 nomor 2 bahwa "Shahibul mal dan mudharib wajib cakap hukum sesuai dengan syariah dan peraturan perundang-undangan yang berlaku". Kedua, Kospin Jasa Syariah menggunakan akad Mudharabah Muthlaqah dalam pelaksanaan pada produk Tabungan Safari. Poin kedua Ini sudah sesuai dengan ketentuan yang berlaku yakni terkait ketentuan dari Fatwa DSN MUI No. 115 tahun 2017 pada butir ke 1 nomor 7 bahwa "Mudharabah muthlaqah adalah akad mudharabah yang tidak dibatasi jenis usaha, jangka waku dan tempat usaha". Maka dalam hal ini pihak Kospin Jasa Syariah dalam mengelola dananya bebas menggunakan untuk jenis investasi apapun asalkan sesuai dengan prinsip syariah.

Ketiga, Terkait penetapkan dana yang diserahkan sebagai modal kepada nasabah dalam hal ini pihak Kospin Jasa Syariah capem banjaran menyerahkannya dalam bentuk uang dan modal yang diserahkan nasabah kepaada Kospin Jasa Syariah. Poin ketiga Ini sudah sesuai dengan ketentuan yang berlaku yakni terkait ketentuan dari Fatwa DSN MUI No. 115 tahun 2017 pada butir ke 5 nomor 1 . Maka dalam hal ini pihak kospin jasa suariah mengakalinya dengan periode jangka waktu peserta tabungan safari per periode, dengan waktu periode selama 36 bulan, maka hal ini dirasa cukup untuk pihak Kospin Jasa Syariah dapat mengembalikan dananya kepada nasabah. Keempat, Terkait pembagian nisbah pihak Kospin Jasa Syariah Capem Banjaran telah menetapkan nominal besaran nisbah yang akan dibagikan dalam kontrak akad, besaran angka nisbah yang akan dibagikan dituangkan dalam akad berbentuk prosentase yaitu 0,05\% bagi nasabah dan 99,5\% bagi Kospin Jasa Syariah. Poin keempat Ini sudah sesuai dengan ketentuan yang berlaku yakni terkait ketentuan dari Fatwa DSN MUI No. 115 tahun 2017 pada butir ke 1 nomor 5 yang menyatakan bahwa "Nisbah adalah bagi hasil atau perbandingan uang yang dinyatakan dengan angka seperti persentase untuk membagi hasil usaha". Kelima, Dalam melakukan akad Tabungan Safari, Kospin Jasa Syariah akan menjelaskan mengenai apa saja ketentuan yang harus di ikuti oleh nasabah sebelum terjadinya ijab qabul atau sebelum nasbah menandatangani kontrak akad. Poin kelima Ini sudah sesuai dengan ketentuan yang berlaku yakni terkait ketentuan dari Fatwa DSN MUI No. 115 tahun 2017 pada butir ke 3 nomor 2 bahwa "Akad mudharabah boleh dilakukan secara lisan, tertulis, isyarat, dan perbuatan atau tindakan, serta dapat dilakukan secara elektronik sesuai syariah dan peraturan perundang-undangan yang berlaku". (DSN MUI, 2017) 
Akan tetapi pada praktiknya, masih ada beberapa ketidaksesuaian Fatwa DSN MUI No. 115/DSN-MUI/IX/2017 tentang Akad Mudharabah, antara lain: Pertama, tentang Akad Mudharabah pada butir ke 8 nomor 1 menjelaskan bahwa "Keuntungan harus dihitung dengan jelas untuk menghindari perbedaan atau sengketa pada waktu alokasi keuntungan". Dari hasil wawancara dengan Bapak Lilik Kuniawan bahwa saat keuntungan telah didapat, pihak Kospin Jasa Syariah tidak menjelaskan mengenai berapa keuntungan yang didapat sehingga bisa mendapatkan wisata tersebut (Kuniawan, 2020). Dilihat dari beberapa nasabah memberikan kritiknya mengenai tidak adanya penjelasan. Dan disaat pendemi corona seperti ini, tidak ada penjelasan mengenai keuntungan berupa wisata tesebut apakah akan ditiadakan atau tetap ada. Diharapkan Kospin Jasa Syariah dapat memaparkan keuntungan yang didapat sehingga mendapatkan wisata tersebut. Dengan memaparkan keuntungan yang didapat, nasabah akan lebih percaya bahwa apa yang diterapkan Kospin Jasa Syariah telah jujur kepada anggotanya.

Kedua, Fatwa DSN MUI No. 115 tahun 2017 tentang Akad Mudharabah pada butir ke 6 nomor 6 bahwa "Nisbah bagi hasil boleh dinyatakan dalam bentuk multinisbah". Multinisbah adalah besarnya nisbah untuk shahibul mal dan mudharib berbeda-berbeda selama berakhirnya periode atau jangka waktu akad. Sedangkan dalam praktiknya, Kospin Jasa Syariah menggunakan single nisbah yaitu besarnya nisbah tetap sama yaitu $0,05 \%$ sampai berakhirnya akad tersebut.

\section{Kesimpulan}

Produk tabungan Safari dari Kopsin Jasa Syariah ini menggunakan akad mudharabah muthlaqah sesuai dengan fatwa DSN MUI No. 115 tahun 2017. Akad mudharabah yang dilakukan di Kopsin ini secara tertulis dan nisbah yang dinyatakan dalam persentase dan disepakati oleh nasabah. Akan tetapi dalam praktinya ada beberapa hal yang tidak sesuai dengan Fatwa DSN MUI yaitu keuntungan harus dihitung dengan jelas. Karena kami jumpai di lapangan Kospin Jasa Syariah kurang jelas dalam memapaparkan keuntungan yang didapat selama pembiayaan, sehingga nasabah belum mengetahui secara detail baik keuntungan ataupun kerugian yang didapat di akhir tahun. Selanjutnya dalam masalah nisbah, dalam aturan yang ada bagi hasil ini bisa berbentuk multinisbah, yakni besarnya nominal nisbah berbeda-beda selama berakhirnya akad. sedangkan Kospin Jasa Syariah menetapkan nominal besarnya nisbah sama sampai berakhinya akad.

\section{Daftar Pustaka}

Anshori, A. G. (2009). Perbankan Syariah Di Indonesia. Yogyakarta: UII Pers.

Arifin, Z. (2009). Dasar-Dasar Manajemen Bank Syariah. Tanggerang: Aztera.

Dewan Syariah Nasional-Majelis Ulama Indonesia (DSN-MUI), (2017). NO: 115/DSN-MUI/LX/2A 17 tentang Akad Mudharabah. Jakarta.

Fatmawati, D. A. (2018). Audit Kepatuhan Syariah Melalui Peran Dewan Syariah Pada PT. BPRS Dana Mulia Surakarta. Journal Of Islamic Finance and Accounting IAIN Surakarta, 19.

Irma Devita Purnamasari, S. (2011). Akad Syariah. Bandung: Kaifa.

Khudori, S. (2018). Analisis Kepatuham Syariah Implementasi Prinsip Bagi Hasil pada Simpanan Mudharabah Di KSPPS Binamas Purworejo. Jurnal Hamfara, 1.

Kuniawan, L. (2020, Maret 23). (D. F. Febriani, Interviewer)

Masni. (2019). Analisis Penerapan Shariah Compliance Dalam Produk Bank Syariah. Jurnal Hukum Ekonomi Syariah, 118.

Muhammad. (2014). Teknik Bagi Hasil dan Margin Keuangan pada Bank Syariah. Yogyakarta: UII Pers. 
Mulazid, A. S. (2016). Pelaksanaan Sharia Compliance Pada Bank Syariah (Studi Kasus Pada Bank Syariah Mandiri, Jakarta). jurnal kajian keislaman madania, 37.

Nitasari, D. (2020, Juli 09). (D. F. Febriani, Interviewer)

Prasetyo, A. T. (2016). Kesesuaian Fatwa DSN MUI No. 7/DSN-MUI/IV/2000 Dalam Produk Pembiayaan Kepada Koperasi Untuk Anggota (PKPA) Di Bank Jatim Syariah Cabang Darmo Kota Surabaya. Jurnal Ekonomi Syariah Teori dan Terapan Unair, 26.

Qulub, A. A. (2019). Kepatuhan Syariah (Sharia Compliance) Akad Mudharabah yang ada di BMT Bina Insan Mandiri Cabang Rengel Tuban dinilai dari Fatwa DSN MUI. Jurnal EkonomiSyariah Teori dan Terapan Unair, 880.

Simamora, A. (1990). Sistem Perbankan Syaiah. Jakarta: PT RINEKA CIPTA.

Sugiyono. (2013). Metode Penelitian Pendidikan Pendekatan Kuantitatif, Kualitatif, dan R\&D. Bandung: Alfabeta.

Suhendi, H. (2007). Fiqh Muamalah: Membahas Ekonomi Islam. Jakarta: PT. Raja Grafindo.

Sutedi, A. (2009). Perbankan Syariah, Tinjauan dan Beberapa Segi Hukum. Jakarta: Ghalia Indonesia. 